\title{
Em busca da realidade urbana: a construção hollywoodiana de Los Angeles
}

\author{
In search of urban reality: \\ Hollywood construction of Los Angeles
}

Maria Helena Braga e Vaz da Costa

\section{Hollywood cinema and the real Los Angeles \\ Reaktion Books, 2012. 336 p.}

Nem o cinema hollywoodiano nem a cidade de Los Angeles podem ser entendidos separadamente, pois existe uma relação simbiótica no que diz respeito à grande influência da cidade na produção dos filmes em Hollywood e, ao mesmo tempo, à enorme participação dos filmes produzidos em Hollywood na formação e no desenvolvimento urbano de Los Angeles. Esta é a principal premissa do mais recente livro de Mark Shiel, Hollywood cinema and the real Los Angeles.

Maria Helena Braga e Vaz da Costa é pós-doutora em Cinema pelo International Institute, University of California at Los Angeles (UCLA), com apoio financeiro da CAPES, e coordenadora do Grupo de Pesquisa Linguagens da Cena: Imagem, Cultura e Representação. É bolsista CNPq (mhcosta@pq.cnpq.br).

Resenha recebida em 8 de janeiro e aprovada para publicação em 11 de março de 2013. 
A premissa é confirmada à medida que o autor investiga, considera e traça as interações da Los Angeles vivenciada na realidade concreta, a cidade real, com as organizações e empresas responsáveis pelo famoso "movie business", isto é, a relação entre a "cidade dos anjos" e os processos de produção, distribuição e exibição dos filmes ali produzidos, focando no período crucial da construção dos primeiros estúdios, ainda nos anos 1910, até o período do declínio do sistema de estúdios, 50 anos depois.

A premissa, apesar de dogmática e possivelmente discutível, não é arduamente defendida pelo autor. Contudo, Shiel defende o argumento de que Los Angeles foi sim determinante para o desenvolvimento da "fábrica de sonhos" hollywoodiana principalmente durante a primeira metade do século XX. Para tanto, ele traça a evolução do cinema de Hollywood em quatro capítulos que empregam o que ele chama de "uma forma espacial" (a spatial motif) para vincular determinados gêneros fílmicos dominantes em determinando período ao que estaria simultaneamente acontecendo na cidade de Los Angeles no contexto do seu desenvolvimento urbano e arquitetônico.

Acompanhando o crescimento e o desenvolvimento urbano de Los Angeles - que acabaria por se tornar uma das dez maiores (em território) cidades no contexto mundial -, e relacionando-os às inúmeras fases pelas quais passou a indústria cinematográfica em Hollywood, Shiel pretende demonstrar como esta última contribuiu largamente tanto para o crescimento de Los Angeles como para as diversas crises no plano econômico, social, político e cultural que atingiram a cidade.

Tendo produtores e diretores pertencido e se engajado no contexto citadino em seu trabalho de produzir e dirigir filmes, seja no interior dos estúdios, seja em locações, a cidade de Los Angeles é um espaço permanentemente presente e por isso é percebida, entendida e discutida por Shiel como essencial para o "formato" dos filmes ali produzidos, que, distribuídos e assistidos em larga escala nacional e internacionalmente, acabaram por influenciar a maneira de ver e imaginar Los Angeles em todo o mundo.

O livro confere atenção ao cinema americano da primeira metade do século XX, mais particularmente às comédias (slapsticks) e sua forma de produção e ao filme noir, gênero essencialmente americano. Cada gênero é então explorado e comentado em suas especificidades enfatizando as peculiaridades da sua representação do espaço urbano e arquitetônico de Los Angeles bem como o estilo e a técnica empregados na filmagem e na produção em geral. Hollywood cinema and the real Los Angeles inclui muitas fotografias e novas evidências históricas proporcionando ao leitor uma experiência de visualização da "cidade dos anjos" a meu ver nunca vista anteriormente.

Mark Shiel apresenta ao leitor uma discussão e explicação realista sobre a maneira como a indústria cinematográfica em Hollywood ofereceu aos espec- 
tadores, em diversas partes do mundo, maneiras de ver e principalmente imaginar o espaço geográfico natural e construído de Los Angeles. Inovadoras são as formas pelas quais Shiel integra a discussão sobre os filmes e seu modo de produção aos modos, atitudes e entendimentos sobre como a indústria hollywoodiana "re-construiu" a cidade.

Los Angeles é uma cidade que condensa e articula diferentes ordens de paisagens: geográfica, geológica, cultural, econômica e política. É um lugar presente no mapa e na grande tela do cinema. Focando em um século de interações e divisões entre a cidade e o cinema que se desenvolveu no seu espaço geográfico, Mark Shiel introduz um novo tipo de ecologia urbana dos filmes, em que a paisagem e o ambiente construído ressoam aos brados na conjuntura do insistente sonho americano relacionado ao espaço e ao lugar, à vida, ao prazer e divertimento e ao local que permite que tudo atue em conjunto.

$\mathrm{O}$ argumento popular sobre Hollywood ter sido fundada para que os filmmakers pudessem escapar do agressivo reforço ao tipo de câmera produzido por Edison no lado leste dos EUA, que se considerou por muito tempo ser verdadeiro, parece ser no mínimo um exagero. Contudo, Shiel argumenta que há algumas evidências de verdade nessa história. Mas os produtores/diretores também se transferiram para Los Angeles por causa da qualidade do clima, que beneficiava seu trabalho oferecendo muitas horas de luz solar, e por causa da variedade oferecida pela paisagem - da costa do Pacífico às montanhas e ao deserto e às Missões Espanholas. Por volta de 1922, Los Angeles era responsável por 84\% de toda a produção cinematográfica nos EUA, e poucos anos mais tarde foi descrita como "a harlot city - gaudy, flamboyant, richly scented, sensuous, noisy, jazzy", como um "three-ring circus".

À medida que Los Angeles começa a se tornar uma cidade, Mark Shiel explica, sua "forma" começa a afetar os filmes que ali eram produzidos e locados. Existe, contudo, um estranho lapso. Shiel relata o "mito" de Raymond Chandler "ter trazido" para o sul da California algo da estratificação por classe dos estilos arquitetônicos tão comuns em sua terra natal, a Inglaterra. Chandler, contudo, nasceu em Chicago e viveu em Nebraska até os 12 anos, e só então mudou-se para a Inglaterra. Retornou aos EUA aos 24 anos de idade e morou em Los Angeles até o fim da vida. Esse seria um pequeno erro se não presumisse que a Inglaterra "monopolizou" a visão de Chandler sobre a arquitetura como produtora de status em termos de classe social. De fato, Chandler poderia ter facilmente aprendido essa lição em Chicago, ou em casa, lendo livros como The great Gatsby. Em outras palavras, Shiel exagera de forma um tanto tendenciosa na tentativa de localizar o significado de Los Angeles em sua particularidade. O capítulo sobre o filme noir em Los Angeles faz um pouco mais do que apenas listar os filmes e reconhecer suas locações no espaço urbano: a Murder, my sweet, referenciado muitas vezes na 
Introdução, são dedicadas apenas poucas páginas no livro; a Sunset Boulevard, duas frases; clássicos noirs locados em Los Angeles como Out of the past, Mildred Pierce e Chinatown não são nem mencionados.

O primeiro capítulo se concentra nos "traços" que podem ser visualizados por meio das imagens da memória, da história, e do aparecimento e sobrevivência da produção cinematográfica no local no período de 1900-1920. O segundo capítulo faz um tipo de "navigation" pelas comédias slapstick dos anos 1920 aos 1930 e mostra a importância da cidade como locação para esse gênero fílmico. O terceiro sugere que o "simulacrum" nos ajuda a ler os filmes sobre os filmes dos anos 1930 em seu contexto na cidade e na sua representação da cidade. Finalmente, o livro termina com o seu mais longo capítulo, sobre os pontos de pressão geopolítica (geopolitical pressure points) nos filmes noirs dos anos 1940 e 1950, aliando-os ao anticomunismo, à caça às bruxas que imperava em Hollywood e aos levantes e revoltas da classe trabalhadora em Los Angeles.

É preciso que se diga que o livro em alguns momentos força determinados entendimentos de forma esquemática. Não fica claro, por exemplo, de que maneiras "traço" e "simulacro" são necessariamente "spatial motifs". Não tenho muita certeza sobre o que Shiel pretende quando afirma que os filmes noirs representam Los Angeles como um "ponto de pressão geopolítico". Também não tenho certeza se isso tem muita importância, mesmo no contexto do que pretende o livro. Contudo, postos em evidência em grande parte do capítulo, os spatial motifs são "usados" por Shiel para interpretar as correlações entre o filme, seu processo de produção e o desenvolvimento urbano. Eles são assim um traço da "navegação", um conceito organizacional latente mais do que uma ativa ferramenta heurística.

É necessário destacar a força e a importância do livro de Mark Shiel, a meu ver consequência do seu profundo conhecimento sobre os filmes que representam Los Angeles e o contexto histórico e cultural da cidade. Tal característica torna este um trabalho de pesquisa acadêmico e interdisciplinar que deve ser inserido não apenas no contexto da área da história do cinema, mas também na dos estudos sociológicos sobre o desenvolvimento urbano no contexto de uma concepção ampla sobre a história americana.

A história do cinema americano, seus gêneros fílmicos e sua relação com a representação da cidade de Los Angeles nunca antes foram tão profundamente analisados como um fenômeno integrado no caso de Hollywood e Los Angeles. O livro de Mark Shiel é finalmente um excelente trabalho de pesquisa e uma importante contribuição para os estudos urbanos e a história cultural do cinema. É, portanto, indispensável aos estudiosos, principalmente da história cinematográfica americana e suas representações de Los Angeles. 